

\title{
Changes in the structural indices of annual shoots of Quercus rubra under anthropogenic impact
}

\author{
V. P. Bessonova, A. P. Kryvoruchko \\ Dnipro State Agrarian-Economic University, Dnipro, Ukraine
}

Article info

Received 27.06.2017

Received in revised form 07.08.2017

Accepted 10.08.2017

Dnipro State

Agrarian-Economic

University,

Sergiy Efremov Str., 25

Dnipro, 49600, Ukraine.

Tel. +38-063-14-208-14

E-mail:

uspeshna18@gmail.com
Bessonova, V. P., \& Kryvoruchko, A. P. (2017). Changes in the structural indices of annual shoots of Quercus rubra under anthropogenic impact. Biosystems Diversity, 25(3), 191-196. doi:10.15421/011729

Air pollution is one of the important problems of large cities. In connection with this, comprehensive study of the mechanisms of the corresponding reactions of tree species, introduced in the process of landscaping, to various environmental factors is required. The aim of this study is to analyze the influence of urban technogenic environmental pollution on the anatomical characteristics of Quercus rubra Linnaeus, 1753 annual shoots. The object of research was 35-year-old plants of Q. rubra, which grew in a non-polluted site (conditionally clean zone), the Botanical Garden of DNU (plot 1) and in a polluted site (roadside planting) (plot 2) of Dnipro City. Industrial emissions of the city's western, northeastern and northwest industrial complexes also have an effect on plants, depending on the wind direction. For anatomical research, the annual shoots were taken at the tips of the vegetation from the south-eastern side of the model trees at a height of $2 \mathrm{~m}$ and fixed in $70 \%$ alcohol. Cross sections were made at a distance of $1 \mathrm{~cm}$ from the beginning of growth. Phloroglucine was used to dye the cells. The influence of industrial and automobile emissions on the structural parameters of $Q$. rubra shoots was investigated. We established that the membrane thickened evenly in both control and experimental plants. Cork thickness of Q. rubra shoots, growing in the roadside plantation was higher than in plants of the Botanical Garden by $57.5 \%$. Increasing its thickness in plants exposed to atmospheric air pollution has an adaptive value. $Q$. rubra shoots have a tabulate type of collenchyma, the tangent walls of whose cells thicken. The collenchyma cells of the control variant of shoots are larger. This tissue was thicker in Q. rubra shoots from the polluted site by $26.8 \%$ compared to those from the non-polluted zone. The parenchyma cells of the primary cortex were large and contained chloroplasts. The thickness of this histological element on the shoot circumference varied considerably both in the control and experimental variants, which is the result of its uneven formation. This is due to the fact that the shape of the shoot core resembles a pentagonal star, and the layers of phloem and xylem tissues repeat its shape. The thickness of each of them in the cross section of the shoots in various places varied little, while the parenchyma of the primary cortex above the ray cells was narrower, and between them was broader, as a result the thickness of the shoots was aligned in a circle. In areas where the parenchyma of the primary cortex was narrower, it was better developed in the shoots of experimental plants than the control ones, but where its layer was thicker, it was more developed in plants of the control variant. The diameter of the primary cortex in the shoots of the experimental variant in its narrower parts was $120.5 \%$ of the control, and in the broader $-87.6 \%$, which is due to unequal changes in the thickness of the primary cortex parenchyma, possibly with different rates of cell division. In the one-year $Q$. rubra shoots, the hard bast resembled a circle ruptured by parenchymal cells. Environmental pollution does not affect formation of soft bast in Q. rubra annual shoots. The difference between the thickness of the layer of this element in the control and experimental plants was statistically insignificant. The width of the bark (soft and hard bast) somewhat decreased in shoots of the roadside trees due to the thinning-out of the hard bast. The thickness of the wood tissue of the $Q$. rubra shoots was practically the same in both variants of the experiment, although it is known that the formation of xylem of certain species of plants is sensitive to environmental pollution. According to our data, the distribution of vessels in the wood of the $Q$. rubra annual shoots on both experimental sites had no clearly expressed annular-vessel type. On the cross section, the vessels are arranged relatively evenly along the width of the entire ring. The location of the woody parenchyma apotracheal does not depend on the location of vessels. Histochemical reactions showed that a large amount of starch grains and fat drops are deposited in the core and ray cells. The diameter of the core was measured in two directions: in narrower and broader places. Plant shoots of the polluted site have a significantly more developed core in the narrower place by 1.44 times, in the broad - 1.56 times. The adaptation of the Q. rubra shoots to technogenic pollution takes place through thickening of the cork and collenchyma, thereby reducing the possibility of penetration into the internal tissues of industrial and automotive emissions. There was virtually no change in the thickness of the circle of soft bast and wood in conditions of environmental pollution. In the conditions of multicomponent environmental pollution there are adaptive changes in the parameters of the histological elements of the Q. rubra shoots - thickening of the phellem and structural element of the primary cortex - collenchyma, which helps to protect the internal tissues from the penetration.of pollutants. Environmental pollution practically did not affect the thickness of the layer of soft bast and wood in the Q. rubra shoots. This testifies to the stability of the most important functions of the Q. rubra shoots to phytotoxicants of anthropogenic origin. The components of industrial and automotive emissions have a negative effect on the formation of hard bast and core of $Q$. rubra shoots, which manifests itself in reduction in their thickness.

Keywords: red oak; anthropogenic impact; characteristics; periderm; primary cortex and bark; wood tissue; shoot 


\title{
Зміна показників структури однорічного пагона Quercus rubra в умовах антропогенного навантаження
}

\author{
В. П. Бессонова, А. П. Криворучко
}

\author{
Дніпровський державний аграрно-економічний університет, Дніпро, Україна
}

Досліджено вплив інгредієнтів промислових та автомобільних викидів на показники анатомічної структури однорічних пагонів Quercus rubra Linnaeus, 1753. Товщина шару корка пагонів рослин Q. rubra, що зростають у придорожньому насадженні, більша, ніж у рослин ботанічного саду ДНУ, на $57,5 \%$. Збільшення ії товщини у рослин в умовах забруднення атмосферного повітря має адаптивне значення. У пагонів Q. rubra коленхіма пластинчастого типу, ії клітини мають потовщення тангентальних стінок. Ця тканина представлена в контролі у середньому 4 радіальними рядами клітин, у досліді - 6 рядами. Клітини коленхіми пагонів контрольного варіанта більші за розмірами. Спостерігається потовщення на 26,8\% цієї тканини в пагонів Q. rubra в умовах забруднення середовища порівняно 3 умовно чистою зоною. Клітини паренхіми первинної кори великі, містять хлоропласти. Товщина цього гістологічного елемента по окружності пагона суттєво змінюється як у контрольному, так і в дослідному варіантах, що є наслідком нерівномірного ії формування. Серцевина пагона за формою нагадує п'ятикутну зірку, а шари флоеми та ксилеми повторюють їі форму. Товщина кожної $з$ них на поперечному зрізі пагона в різних його місцях варіює мало, тоді як паренхіма первинної кори в місцях над променями серцевини вужча, а між ними ширша. За рахунок цього вирівнюється товщина пагона по колу. На ділянках, де паренхіма первинної кори вужча, вона краще розвинена у пагонах дослідних рослин порівняно з контрольними, але там, де ії шар товщий, вона більше розвинена у рослин контрольного варіанта. Діаметр первинної кори у пагонах дослідного варіанта в ії вужчих частинах становить 120,5\% від контролю, а у ширших - 87,5\%. В однорічному пагоні $Q$. rubra твердий луб має вигляд кільця, що розривається ділянками паренхімних клітин. Товщина твердого лубу в пагонах контрольних рослин на 36,5\% більша, ніж за дії на рослини полікомпонентних забруднювачів довкілля. Забруднення довкілля не впливає на формування м'якого лубу однорічних пагонів $Q$. rubra. Різниця між товщиною шару цього елемента в умовах контролю та досліду статистично недостовірна. Ширина шару деревини пагонів $Q$. rubra практично однакова в обох варіантах досліду, хоча відомо, що формування ксилеми деяких видів рослин чутливе до забруднення середовища. Діаметр серцевини вимірювали у двох напрямках (вужчому та ширшому). Пагони рослин забрудненої ділянки мають значно більше (в 1,5 раза) розвинену серцевину у вужчому місці. Розподіл судин у деревині однорічних пагонів Q. rubra на обох дослідних ділянках не має чітко вираженого кільцесудинного типу. На поперечному зрізі судини розташовані відносно рівномірно по ширині всього кільця. Серцевинні промені у пагонах $Q$. rubra численні, зв'язують кору із серцевиною. Клітини серцевинних променів витягнуті в радіальному напрямку. Деякі промені починаються в товщі деревини на різних відстанях від початку тканини. В умовах полікомпонентного забруднення довкілля у показниках гістологічних елементів пагона Q. rubra відбуваються адаптивні зміни: потовщення фелеми та структурного елемента первинної кори - коленхіми, що сприяє кращому захисту внутрішніх тканин від проникнення забруднювачів. Забруднення довкілля практично не впливає на товщину шару м'якого лубу та деревини у пагонах $Q . r u b r a$, що має вагоме значення для збереження показників таких функцій як відтік пластичних речовин у листя та поток до них води 3 мінеральними речовинами. Це свідчить про стійкість важливіших функцій пагона $Q$. rubra до фітотоксикантів антропогенного походження.

Ключові слова: дуб червоний; урботехногенні умови; перидерма; первинна та вторинна кора; деревина; пагін

Вступ

Дуб червоний (Quercus rubra Linnaeus, 1753) - високодекоративна рослина, яка все ширше вводиться в культуру міських насаджень (Dubovickaja and Masalova, 2013; Dubovickaja and Zolotareva, 2014; Klimovich et al., 2014; Gvozdev and Hohlov, 2016; Krasnov et al., 2016; Miltner and Kupka, 2016). Однак у населених пунктах Південного Сходу України його використовують поки мало, що пов'язано зі слабкою вивченістю відповідних реакцій на специфічні кліматичні умови цього регіону. Мала кількість опадів на рік (400-450 мм), часті посухи, зимові відлиги з подальшим різким зниженням температури, а також високий рівень забруднення атмосферного повітря та грунтів промислових міст цього регіону, у зв'язку з розвиненою промисловістю та високою інтенсивністю автомобільного руху, створюють специфічні умови для зростання інтродуцентів.

Забруднення повітря - одна з важливих проблем великих міст. Вагоме місце серед забруднювачів належить викидам автотранспорту (Saikawa, 2011; Fu et al., 2017; Song et al., 2017). Ступінь пошкодження рослин у таких умовах залежить від концентрації та тривалості дії на них полютантів. Цей вплив тією чи іншою мірою відображається на вегетації дерев (Saborit, 2009), морфометричних показниках (Bojarczuk et al., 2002; Leghari and Zaidi, 2013), рості та розвитку (Rai, 2016; CarvalhoOliveira et al., 2017; Doley, 2017).

У пізнанні механізмів відповідних реакцій інтродукованих деревних рослин на різні екологічні фактори істотна роль належить анатомічним дослідженням їх органів, оскільки умови росту накладають відбиток на розвиток гістологічних елементів ї тканин (Tjurina, 1982; Kapeljush and Bessonova, 2005; Gostin, 2009; Safdari et al., 2012; Jusypiva and Grycaj, 2014).

Кількісно-анатомічні методи дозволяють також повно та всебічно зрозуміти значення для рослин тих чи інших змін у їх будові за дії певних факторів (Nikolaevskij, 1964). Вони можуть слугувати індикаторними показниками техногенного забруднення атмосферного повітря (Wimmer, 2002; Braun et al., 2007; Kaakinen et al., 2007; Kurteva and Stambolieva, 2007; Mohamed et al., 2016; Stratu et al., 2016).

Мета цього дослідження - оцінити вплив урботехногенного забруднення середовища на анатомічні характеристики однорічних пагонів $Q$. rubra.

\section{Матеріал і методи досліджень}

Як об'єкт дослідження використовували 35-річні рослини Q. rubra, які зростали в умовно чистій зоні - ботанічному саду ДНУ імені Олеся Гончара (ділянка 1) та у придорожньому насадженні м. Дніпро (ділянка 2). Інтенсивність руху автотранспорту становить 49400 машин на добу. Це спричиняе високий рівень забруднення шкідливими складовими відпрацьованих газів автотранспорту $\left(\mathrm{NO}_{2}, \mathrm{SO}_{2}\right)$, а також фенолів, формальдегідів, пилу, бензолу та сажі у концентраціях, які в атмосферному повітрі (за даними санітарно-епідеміологічної станції) у зв'язку з експлуатацією автомобільних доріг становлять понад 2,5 ГДК. Ця ділянка розташована у пониженому районі міста (56,8 м над рівнем моря). Саме це робить можливим прогресивне накопичення полютантів у повітрі (Bezuglaja et al., 1991; Serdjuk et al., 2007). На ділянку 2 надходять також інгредієнти промислових викидів Західного, Північно-Східного та Північно-Західного промислових комплексів (Pasichnyj and Serdjuk, 2002), залежно від мінливості напрямку вітру. Відстань від них становить 4,5, 2,7-4,4 і 2,9-3,8 км, відповідно.

Для анатомічних досліджень однорічні пагони відбирали в кінці вегетації з південно-східного боку модельних дерев на висоті 2 м і фіксували 70\% етиловим спиртом. Поперечні зрізи робили на відстані 1 см від початку приросту. Для забарвлю- 
вання здерев'янілих клітин використовували розчин флороглюцину (Dzhensen, 1965). Вимірювання гістологічних елементів структури пагона здійснювали за допомогою мікроскопа Біомед-4 із використанням окуляр-мікрометра. Відзначали характер розташування тканин, особливості їх будови. Кількість розглянутих препаратів у кожному варіанті - 25-30. Результати експерименту оброблені статистично: розраховували помилку середнього арифметичного, обчислювали критерій достовірності відмінностей між показниками варіантів (t-test) після встановлення нормальності розподілу вибірки.

\section{Результати та їх обговорення}

Система покривних тканин вторинного походження (перидерма) включає власне покривну тканину - фелему (корок), шар вторинної меристеми - фелоген і внутрішню тканину фелодерму. Клітини корки на поперечному зрізі пагона прямокутні. Середня кількість їх рядів у контролі $-4-5$, у досліді6-7 (рис. 1). Потовщення оболонки рівномірне. Товщина шару корка пагонів рослин $Q$. rubra, що зростають у придорожньому насадженні, на 57,5\% більша, ніж у рослин ботанічного саду. Фелодерма на поперечному зрізі представлена двома рядами клітин, відмінностей по ії товщиної між контролем і дослідом не виявлено.

Фелемі належить важлива роль в адаптивних реакціях рослин. Завдяки щільному змиканню клітин і наявності в оболонках суберинового шару вона захищає розташовані нижче тканини від зайвих витрат води внаслідок випаровування, а також від різких коливань температури (Kursanov et al., 1952). Вона також перешкоджає проникненню у тканини токсичних газів забрудненого повітря. Таким чином, збільшення іiі товщини у рослин $Q$. rubra в умовах забруднення атмосферного повітря має адаптивне значення. Відмічається також, що зимостійкість пагонів пропорційна ступеню розвитку перидерми, що показано на такому об'єкті як магнолія (Pallachega et al., 2007).

Згідно з літературними даними, характер змін товщини перидерми пагонів в умовах забруднення середовища визначається видовими особливостями рослин. Jusypiva and Grycaj (2014) виявили іï потоншення на пагонах Caragana arborescens Lam. під час вивчення впливу на рослини промислових емісій $\mathrm{NO}_{2}$ та $\mathrm{SO}_{2}$. Збільшення шару вторинної покривної тканини пагонів Fraxinus excelsior L. установлено за дії на рослини полютантів, i, навпаки, зменшення іï - у $F$. pensilvanica Marshall (Jusypiva, 2005). Потовщення перидерми у видів роду Acer встановлено Golykova (2011) за впливу викидів Придніпровської TEC, особливо в Acer pseudoplatanus L. (в 1,5 раза).

Під фелодермою пагона Q. rubra міститься шар механічної тканини - коленхіми пластинчастого типу, клітини якої мають потовщення тангентальних стінок. Ця тканина представлена в контролі в середньому чотирма радіальними рядами клітин, у досліді - шістьма рядами (рис. 1). Клітини коленхіми пагонів контрольного варіанта більші за розмірами. Спостерігається потовщення цієї тканини пагонів Q. rubra в умовах забруднення середовища порівняно 3 контрольною зоною на 26,8\% (табл. 1). Коленхіма виконує «арматурну» функцію, має здатність до значних деформацій.

Під коленхімою розташовується шар клітин паренхіми первинної кори, представленої великими клітинами з хлоропластами. Товщина цього гістологічного елемента по окружності пагона суттєво змінюється як у контрольному, так і в дослідному варіантах, що $є$ наслідком нерівномірного іiі формування (рис. 2). Це пов'язано $з$ тим, що серцевина пагона формою нагадує п'ятикутну зірку, а шари тканин флоеми та ксилеми повторюють іiі форму; товщина кожної з них на поперечному зрізі пагона в різних його місцях варіює мало, у той час як паренхіма первинної кори в місцях над променями серцевини вужча, а між ними - ширша. За рахунок цього вирівнюється товщина пагона по колу. На ділянках, де паренхіма первинної кори вужча, вона краще розвинена у пагонах дослід- них рослин, порівняно $з$ контрольними. Але там, де її шар товщий, вона більше розвинена у рослин контрольного варіанта.

Коленхіма та паренхіма утворюють первинну кору. Діаметр первинної кори у пагонах дослідного варіанта в її вужчих частинах становить $120,5 \%$ від контролю, а у ширших $-87,5 \%$, що пов'язано з неоднаковими змінами товщини паренхіми первинної кори, можливо, неоднаковими темпами поділу клітин.

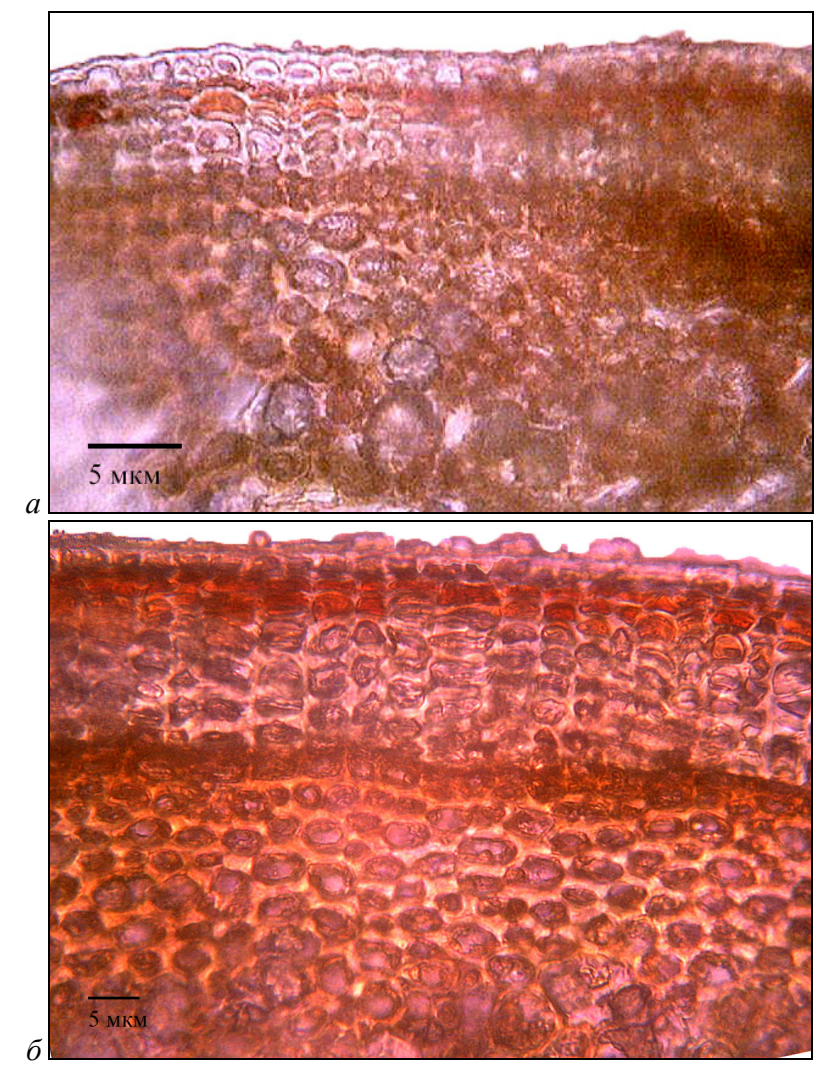

Рис. 1. Вторинна покривна тканина (перидерма) та коленхіма однорічних пагонів Q. rubra:

$a$ - ботанічний сад, $\sigma$ - придорожнє насадження

\section{Таблиця 1}

Вплив урботехногенного забруднення на товщину елементів первинної кори однорічного пагона $Q . r u b r a(\mathrm{x} \pm \mathrm{SD}, \mathrm{n}=30)$

\begin{tabular}{lrr}
\hline \multicolumn{1}{c}{ Структурні елементи } & Контроль & \multicolumn{1}{c}{ Дослід* } \\
\hline Фелема & $33,4 \pm 1,1$ & $52,6 \pm 1,3$ \\
Корок & $54,2 \pm 2,1$ & $72,3 \pm 1,3$ \\
Коленхіма & $59,3 \pm 0,8$ & $75,2 \pm 1,6$ \\
Паренхіма первинної кори: & & \\
Менша ширина & $69,0 \pm 1,0$ & $79,4 \pm 1,2$ \\
Більша ширина & $210,9 \pm 5,1$ & $161,4 \pm 4,6$ \\
Первинна кора: & & \\
Менша ширина & $128,3 \pm 3,5$ & $154,6 \pm 2,8$ \\
Більша ширина & $270,2 \pm 3,1$ & $236,5 \pm 5,1$ \\
\hline
\end{tabular}

Примітка: * - різниця між контрольним і дослідним варіантами статистично достовірна за $\mathrm{P}<0,05$.

Аналогічні результати щодо збільшення товщини коленхіми у пагонах Salix alba L. отримали Jusypiva and Miasoid (2016). Проте, якщо в дослідах цих авторів спостерігали потовщення також і паренхіми первинної кори, то у пагонів Q. rubra за дії полікомпонентних забруднювачів відбуваються різноспрямовані зміни ширини цього гістологічного елемента первинної кори стосовно показників контролю залежно від місця розташування.

Деякі автори спостерігали потоншення первинної кори пагонів у таких видів як Robinia pseudoacacia L., Populus nigra L., $P$. deltoides W. Bartram ex Marshall за середнього та сильного забруднення незалежно від ступеня стійкості рослин (Grishko et al., 1997).

Флоема - тканина, головна функція якої полягає у проведенні пластичних речовин (низхідний потік), представлена 
м'яким і твердим лубом. М'який луб - комплекс анатомічних елементів, що складається із ситоподібних трубок і клітин, які до них примикають, а пучки луб'яних волокон складають твердий луб. В однорічному пагоні $Q$. rubra твердий луб має вигляд кільця, що розривається ділянками паренхімних клітин (рис. 3). Шар цих клітин, оболонки яких здерев'янілі (реакція 3 флороглюцином), сильно та рівномірно потовщені, у пагонах контрольних рослин ширший, ніж за дії на рослини полікомпонентних забруднювачів довкілля на $36,5 \%$.

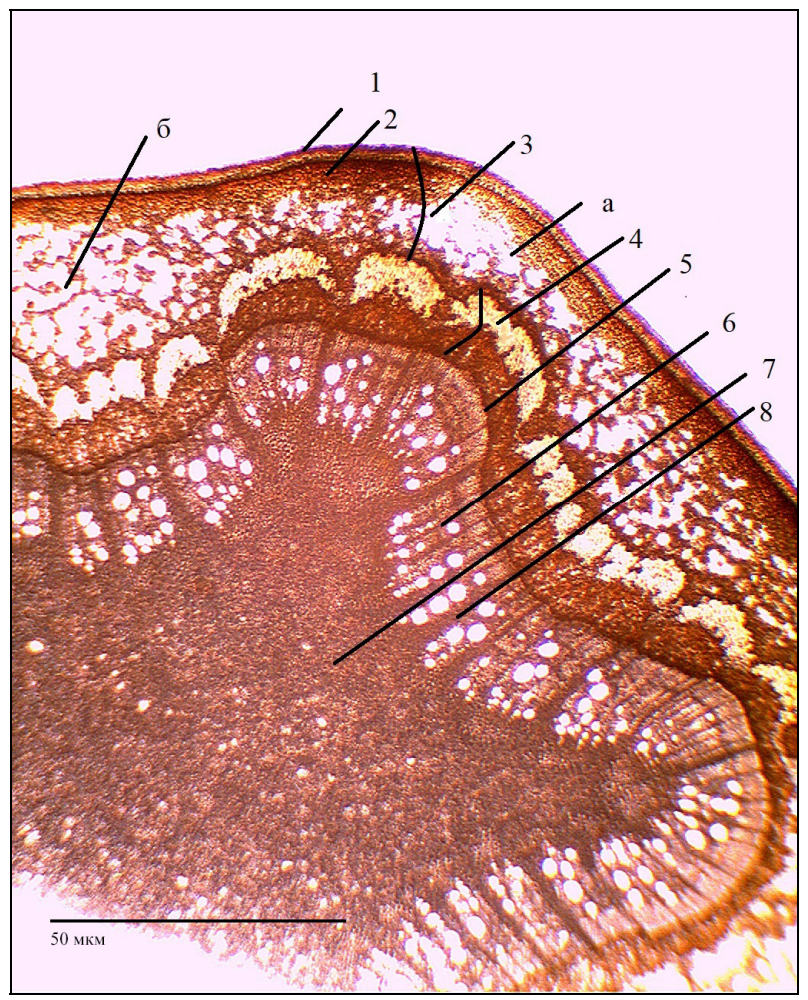

Рис. 2. Нерівномірність потовщення шару паренхіми первинної кори у пагонах $Q$. rubra: 1 - перидерма; 2 - коленхіма; 3 - первинна кора: $a$ - паренхіма первинної кори за меншою шириною, $\sigma$ - паренхіма первинної кори за більшою величиною; 4 - вторинна кора (луб); 5 - камбій;

6 - деревина; 7 - серцевина; 8 - серцевинні промені

Забруднення довкілля не впливає на формування м'якого лубу в однорічних пагонів Q. rubra. Різниця між товщиною шару цього структурного елемента в умовах контролю та досліду статистично недостовірна, що важливо для збереження нормального функціонування пагонів та відтоку пластичних речовин, синтезованих у листках, в інші органи (табл. 2).

\section{Таблиця 2}

Вплив антропогенного забруднення на товщину елементів вторинної кори (мкм, $\mathrm{x} \pm \mathrm{SD}, \mathrm{n}=25$ )

\begin{tabular}{lcccc}
\hline \multicolumn{1}{c}{ Варіант } & М'який луб & Твердий луб & Вторинна кора & Деревина \\
\hline Контроль & $141,6 \pm 3,3$ & $101,4 \pm 2,2$ & $243,0 \pm 6,4$ & $270,9 \pm 5,4$ \\
Дослід & $151,1 \pm 4,2$ & $65,0 \pm 1,1 *$ & $216,1 \pm 5,0^{*}$ & $274,1 \pm 4,4$ \\
\hline
\end{tabular}

Примітка: * - різниця між контрольним і дослідним варіантами статистично достовірна за $\mathrm{P}<0,05$.

Ширина вторинної кори (м'який і твердий луб) дещо зменшується у пагонів рослин придорожнього насадження за рахунок потоншення твердого лубу. За літературними даними вплив забруднювачів на розвиток вторинної кори залежить від виду рослин. У пагонах Caragana arborescens Lam. частка ії елементів зменшується відносно контролю (Jusypiva and Grycaj, 2014).

Ширина шару деревини пагонів $Q$. rubra практично однакова в обох варіантах досліду (табл. 2). Хоча відомо, що формування ксилеми деяких видів рослин чутливе до забруднення середовища. У Tilia cordata Mill. за дії викидів ТЕС у дворічних пагонах утворюється нерівномірно розширене кільце ксилеми, розмір якого на деяких ділянках удвічі більший, порівняно 3 іншими ділянками одного і того ж препарату (Grycaj and Shupranova, 2015). А згідно з Jarmishko (2012), мають місце випадки часткового та повного випадіння річних шарів деревини у Pinus sylvestris L. за впливу викидів твердих частинок міднонікелевого комбінату. Зниження ширини шару деревини у пагонах Betula pendula Roth в умовах забруднення середовища спостерігала Jusypiva (2016).
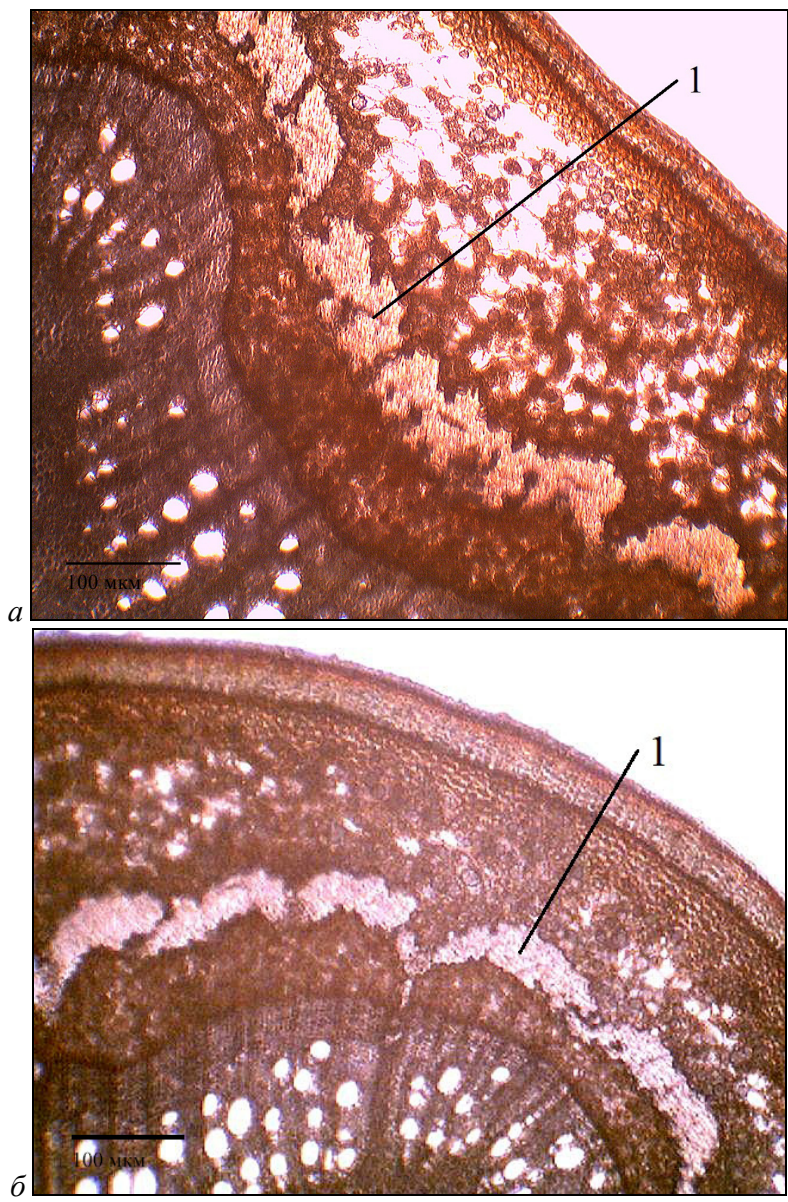

Рис. 3. Вплив забруднення довкілля на товщину склеренхіми (1) твердого лубу пагонів $Q$. rubra: $a$ - ботанічний сад, $\sigma$ - придорожнє насадження

Діаметр судин ранньої деревини Q. rubra набагато ширший за такий у пізній деревині, що дозволяє віднести ії до кільцепорової (кільцесудинної) (Rejvn et al., 1999). Проте, за нашими даними, розподіл судин у деревині однорічних пагонів Q. rubra на обох дослідних ділянках не має чітко вираженого кільцесудинного типу. На поперечному зрізі судини розташовані відносно рівномірно по ширині всього кільця (рис. 3). Jessau (1969) вказує, що в межах одного виду розподіл судин може варіювати залежно від зовнішніх умов і віку дерева (пагона). Цей автор наводить ілюстрацію півкільцесудинної деревини Quercus virginiana Mill. Деревна паренхіма апотрахіальна, iii розташування не залежить від розташування судин.

Численні серцевинні промені у пагонах $Q$. rubra зв'язують кору із серцевиною. Клітини серцевинних променів витягнені в радіальному напрямку. Деякі промені починаються у товщі деревини на різних відстанях від початку тканини.

Серцевина сильно розвинена і має, як було вказано вище, обрис, що нагадує п'ятикутну зірку. Вона складається з округлих великих клітин, розміри яких збільшуються від периферії до центра. Гістохімічними реакціями встановлено, що у клітинах серцевини та серцевинних променів відкладається велика 
кількість крохмальних зерен і крапель жиру. Діаметр серцевини вимірювали у двох напрямках: у нійвужчому та найширшому місцях. Пагони рослин забрудненої ділянки мають значно розвиненішу серцевину в найвужчому місці (в 1,5 раза), у найширшому - лише в 1,4 раза (табл. 3 ).

Таблиця 3

Вплив урботехногенного забруднення довкілля на розміри серцевини та величини співвідношення основних елементів пагона $(\mathrm{x} \pm \mathrm{SD}, \mathrm{n}=30)$

\begin{tabular}{lcccc}
\hline \multirow{2}{*}{ Варіант } & \multicolumn{2}{c}{ Радіус серцевини, мкм } & \multicolumn{2}{c}{$\begin{array}{c}\text { Співвідношення } \\
\text { (у відносних одиницях) }\end{array}$} \\
\cline { 2 - 5 } & $\begin{array}{c}\text { широка } \\
\text { частина }\end{array}$ & $\begin{array}{c}\text { вузька } \\
\text { частина }\end{array}$ & $\begin{array}{c}\text { первинна кора до } \\
\text { вторинної кори }\end{array}$ & $\begin{array}{c}\text { вторинна кора } \\
\text { до деревини }\end{array}$ \\
\hline Контроль & $814,1 \pm 11,3$ & $521,2 \pm 12,9$ & $\frac{0,58}{1.11} * *$ & 0,90 \\
Дослід & $551,9 \pm 15,3 *$ & $380,2 \pm 9,7 *$ & $\underline{\underline{0.71}} * *$ & 0,79
\end{tabular}

Примітки: * - різниця між контрольним і дослідним варіантами статистично достовірна за $\mathrm{P}<0,05$; ** - у чисельнику розраховано відношення первинної кори за меншою шириною до вторинної кори, у знаменнику - за більшою шириною.

Із результатами нашого дослідження узгоджуються дані щодо зменшення діаметра серцевини в умовах забруднення навколишнього середовища промисловими викидами у Рориlus deltoides, P. italica і Robinia pseudoacacia. Разом із цим визначено, що зміни кількості серцевинних променів та діаметра серцевини статистично достовірно не залежать від сумарного рівня забруднення повітря на моніторингових ділянках (Grishko et al., 1997).

У процесі еволюційного розвитку рослинні організми виробили певний адаптаційний потенціал до різних факторів середовища (Zhuchenko, 1988). У разі відхилення їх від норми відбувається реалізація цього потенціалу за допомогою генетичних, біохімічних, фізіологічних і морфоанатомічних механізмів (Zhuchenko, 1988; Korshikov, 1996), тобто за рахунок структурно-функціональних і морфоанатомічних перебудов у межах норми реакції. Grodzinskij (1983) розглядає здатність рослинних адаптацій до умов навколишнього середовища, що змінюються, як прояв надійності. Надійність - властивість об' єкта виконувати свою функцію протягом даного часу в даних умовах. Реалізація адаптивного потенціалу до техногенного забруднення навколишнього середовища пагонів Q. rubra відбувається за рахунок потовщення корка та коленхіми, завдяки чому зменшується можливість проникнення у внутрішні тканини інгредієнтів промислових і автомобільних викидів. Товщина кільця м'якого лубу та деревини в умовах забруднення середовища практично не змінюється, що має велике значення для збереження показників відтоку пластичних речовин із листя та потоку до них води з мінеральними речовинами, тобто утримання функцій цих тканин на рівні контролю.

\section{Висновки}

За полікомпонентного забруднення довкілля у показниках гістологічних елементів пагона $Q$. rubra відбуваються адаптивні зміни: потовщення фелеми та структурного елемента первинної кори - коленхіми. Це сприяє кращому захисту внутрішніх тканин від проникнення забруднювачів.

Забруднення довкілля практично не впливає на товщину шару м'якого лубу та деревини у пагонах $Q . r u b r a$, що має вагоме значення для збереження показників таких важливих функцій, як відтік пластичних речовин у листя і потік до них води 3 мінеральними речовинами. Це свідчить про стійкість найважливіших функцій пагона Q. rubra до фітотоксикантів антропогенного походження. Інгредієнти промислових і автомобільних викидів негативно впливають на формування твердого лубу та серцевини пагона Q. rubra, що проявляється у зменшенні їх товщини.

\section{References}

Bezuglaja, J. J., Rastorgueva, G. P., \& Smirnova, I. V. (1991). Chem dyshit promyshlennyj gorod [What an industrial city breathes]. Gidrometeoizdat, Leningrad (in Russian).

Bojarczuk, K., Karolewski, P., Oleksyn, J., Kieliszewska-Rokicka, B., Zytkowiak, M., \& Tjoelker, G. (2002). Effect of polluted soil and fertilisation on growth and physiology of Silver Birch (Betula pendula Roth.) seedlings. Polish Journal of Environmental Studies, 11(5), 483-492.

Braun, M., Margitai, Z., Toth, A., \& Leermakers, M. (2007). Environmental monitoring using linden tree leaves as natural traps of atmospheric deposition: A pilot study in Transilvania, Romania. AGD Landscape and Environment, 1(1), 24-35.

Carvalho-Oliveira, R., Amato-Lourenço, L. F., Moreira, T. C. L., Rocha Silva, D. R., Vieira, B. D., Mauad, T., Saiki, M., \& Nascimento Saldiva, P. H. (2017). Effectiveness of traffic-related elements in tree bark and pollen abortion rates for assessing air pollution exposure on respiratory mortality rates. Environment International, 99, 161-169.

Doley, D. (2017). Plants as pollution monitors. Encyclopedia of Applied Plant Sciences (Second Edition), 3, 341-346.

Dubovickaja, O. J., \& Masalova, L. I. (2013). Perspektivy rasshirenija ustojchivogo assortimenta drevesnyh rastenij dlja landshaftnogo stroitel'stva i ispol'zovaniem severoamerikanskih introducentov [Prospects for expanding the sustainable range of woody plants for landscape construction using exotic species of North American introductions]. Contemporary Horticulture, 4, 8091 (in Russian).

Dubovickaja, O. J., \& Zolotareva, E. V. (2014). Dekorativnolistvennye i hvojnye derev'ja i kustarniki dlja ozelenenija naselennyh mest [Ornamental deciduous and coniferous woody plants for arrangement of green spaces in cities and towns of orel region]. Belgorod State University Scientific Bulletin. Natural Sciences, 29(23), 38-43 (in Russian).

Dzhensen, U. (1965). Botanicheskaja gistohimija [Botanical Histochemistry]. Mir, Moscow (in Russian).

Fu, S., \& Gu, Y. (2017). Highway toll and air pollution: Evidence from Chinese cities. Journal of Environmental Economics and Management, 83, 32-49.

Golykova, M. (2011). Vplyv promyslovogo zabrudnennja na elementy anatomichnoi' struktury pagoniv kleniv [Influence of industrial pollution on elements of anatomic structures of shoots of maples]. Visnyk of the Lviv University. Series Biology, 57, 242-248 (in Ukrainian).

Gostin, I. (2009). Air pollution effects on the structure of some Fabaceae spacies. Notulae Botanicae Horti Agrobotanici Cluj-Napoca, 37(2), 57-63.

Grishko, V. N., Kuchma, V. N., \& Radzion, D. V. (1997). Anatomicheskoe stroenie pobegov nekotoryh drevesnyh rastenij pri zagrjaznenii okruzhajushhej sredy [Anatomical structure of shoots some woody plants with pollution of the environment]. Questions of Bioindication and Ecology, 49-54 (in Russian).

Grodzinskij, D. M. (1983). Nadezhnost' rastitel'noj sistemy [Reliability of the plant system]. Naukova dumka, Kyiv (in Russian).

Grycaj, Z. V., \& Shupranova, L.V. (2015). Vplyv vykydiv Prydniprovs'koi' TES m. Dnipropetrovs'k na anatomichni pokaznyky stebla dvorichnogo pagona predstavnykiv rodu Tilia [Impact of emissions of Pridneprovsk TPP in Dnipropetrovsk on the anatomical indices of stem of two-year whip of the Tilia genus representatives]. Visnyk of Dnipropetrovsk University. Biology, Ecology, 23(2), 230-235 (in Ukrainian).

Gvozdev, V. K., \& Hohlov, A. A. (2016). Osobennosti rosta i produktivnost' nasazhdenij iskusstvennogo proishozhdenija mestnyh i introducirovannyh drevesnyh vidov [Features of growth and productivity plants artificial origin local and introduced tree species]. Proceedings of Belarusian State Technological University, 183, 106-109 (in Russian).

Jarmishko, V. T. (2012). Hod rosta Pinus sylvestris L. na severnom predele rasprostranenija $\mathrm{v}$ uslovijah atmosfernogo zagrjaznenija [The cource of growth of a Pinus sylvestris L. in the northern limit of distributions in the conditions air pollution]. Izvestiya of the Samara Scientific Center of the Russian Academy of Sciences, 1(6), 1575-1580 (in Russian).

Jessau, K. (1969). Anatomija rastenij [Anatomy of plants]. Mir, Moscow (in Russian).

Jusypiva, T., \& Miasoid, G. (2016). The impact of $\mathrm{SO}_{2}$ and $\mathrm{NO}_{2}$ industrial emission anatomical stem of Salix alba. International Letters of Nature Science, 51, 6-13.

Jusypiva, T. I., \& Grycaj, Z. V. (2014). Vplyv aerogennogo zabrudnennja $\mathrm{NO}_{2}$ ta $\mathrm{SO}_{2}$ na anatomichni pokaznyky stebla Caragana arborescens Lam. [Influence of aerogenic $\mathrm{SO}_{2}$ and $\mathrm{NO}_{2}$ pollution on anatomic parameters of Caragana arborescens Lam. stem]. The Journal of V. N. Karazin Kharkiv National University. Series Biology, 1129, 123-127 (in Ukrainian).

Jusypiva, T. I. (2005). Vplyv promyslovogo zabrudnennja na gistologichni pokaznyky pervynnoi' kory stebla predstavnykiv rodu Fraxinus L. [Industrial pollution influence on histological indices of stem primary bark of 
Fraxinus L. genus representatives]. Visnyk of Dnipropetrovsk University. Biology, Ecology, 13(1), 295-301 (in Ukrainian).

Jusypiva, T. I. (2016). Zminy anatomichnyh harakterystyk stebla odnorichnogo pagona Betula pendula Roth. za dii' antropogennogo navantazhennja [Changes in anatomical characteristics of Betula pendula Roth. annual shoot stems under anthropogenic load pressure]. Visnyk of the Lviv University. Series Biology, 72, 125-133 (in Ukrainian).

Kaakinen, S., Kostianen, K., Saranpaa, P., Kubiske, M., Sober, J., Karnosky, D. F., \& Vapaavuri, E. (2007). Stem wood properties of Populus tremula, Betula papyrifera and Acer saccharum sapling after 3 years of treatment to elevated carbon dioxide and ozone. Global Change Biology, 10, 1513-1525.

Kapeljush, N. N., \& Bessonova, V. P. (2005). Zmina anatomichnyh pokaznykiv lystkiv Platanus orientalis L. pid dijeju promyslovyh emisij (tehnogennogo navantazhennja) [Change of anatomic parameters of Platanus orientalis L. leaves as reaction on industrial emissions (technogenic pressure)]. Plant Introduction, 1, 81-87 (in Ukrainian).

Klimovich, L. K., Efimenko, V. M., \& Mitik, N. V. (2014). Osobennosti landshaftnoj planirovochnoj organizacii dendroparka GLHU "Grodnenskij leshoz" [The peculiarities of landscape planning the organization of the park of the Grodno forestry]. Actual Problems of the Forestry Complex, 38, 175179 (in Russian)

Korshikov, I. I. (1996). Adaptacija rastenij k uslovijam tehnogennogo zagrjaznenija sredy [Adaptation of plants to the conditions of technogenic contamination of the environment]. Naukova Dumka, Kyiv (in Russian).

Krasnov, V. G., Mamaev, A. A., Smyshljaeva, M. I., Krasnova, V. F., \& Kirillov, S. V. (2016). Osobennosti introdukcii duba krasnogo (Quercus rubra) v uslovijah respubliki Marij Jel [Introduction features of red oak (Quércus rúbra) in Mari El Republic]. Electronic Scientific Journal of KubSAU, 123(9), 1968-1378 (in Russian).

Kursanov, L. I., Komarnyc'kyj, M. O., Mejjer, K. G., Razdors'kyj, V. F., \& Uranov, O. O. (1952). Botanika. Anatomija i morfologija [Botany. Anatomy and morphology]. Radjans'ka Shkola, Kyiv (in Ukrainian).

Kurteva, M., \& Stambolieva, K. (2007). Acer pseudoplatanus L., Acer platanoides L. and Betula pendula Roth. as bioindicators of urban pollution in Sofia. Silva Balcanica, 8(1), 32-46.

Leghari, S. K., \& Zaidi, M. A. (2013). Effect of air pollution on the leaf morphology of common plant species of Quetta city. Pakistan Journal of Botany, 45(S1), 447-454.

Miltner, S., \& Kupka, I. (2016). Silvicultural potential of northern red oak and its regeneration. Journal of Forest Science, 62, 145-152.

Mohamed, A. H., M'hamed, M., Fatma, M., \& Hichem, B. M. (2016). Air pollution mapping with bio-indicators in urban areas. In Sallis, P. (Ed.), Air quality - Measurement and modeling. InTech, Rijeka, Croatia, pp. 163-183.

Nikolaevskij, V. G. (1964). K metodike kolichestvenno-anatomicheskogo izuchenija vlijanija vneshnej sredy na strukturu vegetativnyh organov vysshih rastenij [To the method of quantitative-anatomical study of the influence of the external environment on the structure of the vegetative organs of higher plants]. Botanical Journal, 49(6), 833-838 (in Russian).
Pallachega, R. M., Kytajev, O. I., \& Taran, N. J. (2007). Morozostijkist' magnolij ta l'odoutvorennja u tkanynah pagoniv [Frost resistance of magnolias and ice formation in shoots]. Ukrainian Botanical Journal, 64(6), 891-900 (in Ukrainian).

Pasichnyj, G. V., \& Serdjuk, S. M. (2002). Dynamika vazhkyh metaliv v gruntovomu pokryvi u zv'jazku z tehnogennym zabrudnennjam otochujuchogo seredovyshha (na prykladi m. Dnipropetrovs'ka) [Dynamics of heavy metals in the soil cover due to anthropogenic pollution of the environment (for example, Dnipropetrovsk)]. Ecology and Nature Management, 4, 111-117 (in Ukrainian).

Rai, P. K. (2016). Impacts of particulate matter pollution on plants: Implications for environmental biomonitoring. Ecotoxicology and Environmental Safety, $129,120-136$

Rejvn, P., Jeveret, R., \& Ajkhom, S. (1990). Sovremennaja botanika [Contemporary botany]. Mir, Moscow (in Russian).

Saborit, J. (2009). Effects of air pollution on citrus tree. Tree and Forestry Science Biotechnology, 3, 92-104.

Safdari, V., Ahmed, M., Margaret, S., Devall, M., \& Bayramzadeh, V. (2012) Effects of air pollution on morphological and anatomical characteristics of Pinus eldarica wood. Fuuast Journal of Biology, 2(2), 5-12.

Saikawa, E., Kurokawa, J.,Takigawa, M., Borken-Kleefeld, J., Mauzerall, D. L., Horowitz, L. W., \& Ohara, T. (2011). The impact of China's vehicle emissions on regional air quality in 2000 and 2020: A scenario analysis. Atmospheric Chemistry. Physics, 11, 9465-94840.

Serdjuk, S. M., Docenko, L. V., \& Sybul', T. V. (2007). Naukove obgruntuvannja fitomelioratyvnyh zahodiv v umovah vysokogo avtotransportnogo navantazhennja [Scientific substantiation of phytomelioration measures in the conditions of high motor loading]. Issues of Steppe Forestry and Steppe Recultivation Land, 36, 192-200 (in Ukrainian).

Song, C., Wu, L., Xie, Y., He, J., Chen, X., Wang, T., Yingchao, L., Jin, T., Wang, A., Liu, Y., Dai, G., Liu, B., Wang, Y., \& Mao, H. (2017). Ai pollution in China: Status and spatiotemporal variations. Environmental Pollution, 227, 334-347.

Stratu, A., Costica, N., \& Costica, M. (2007). Wooden species in the urban green areas and their role in improving the quality of the environment. Present Environment and Sustainable Development, 10(2), 173-184.

Tjurina, E. V. (1982). Znachenie anatomicheskogo metoda dlja vyjasnenija proishozhdenija adaptacionnyh i introdukcionnyh vozmozhnostej rastenij [The value of the anatomical method for elucidating the origin of adaptive and introductory possibilities of plants]. In Non-traditional methods in studies of vegetation in Siberia. Nauka, Novosibirsk, 77-88 (in Russian).

Wimmer, R. (2002). Wood anatomical features in tree-rings as indicators of environmental change. Dendrochronologia, 20, 21-36.

Zhuchenko, A. A. (1988). Adaptivnyj potencial kul'turnyh rastenij (jekologogeneticheskie osnovy) [Adaptive potential of cultivated plants (ecological and genetic basis)]. Shkiinca, Kishinev (in Russian). 